Journal of

Business and Strategic

Management

(JBSM)

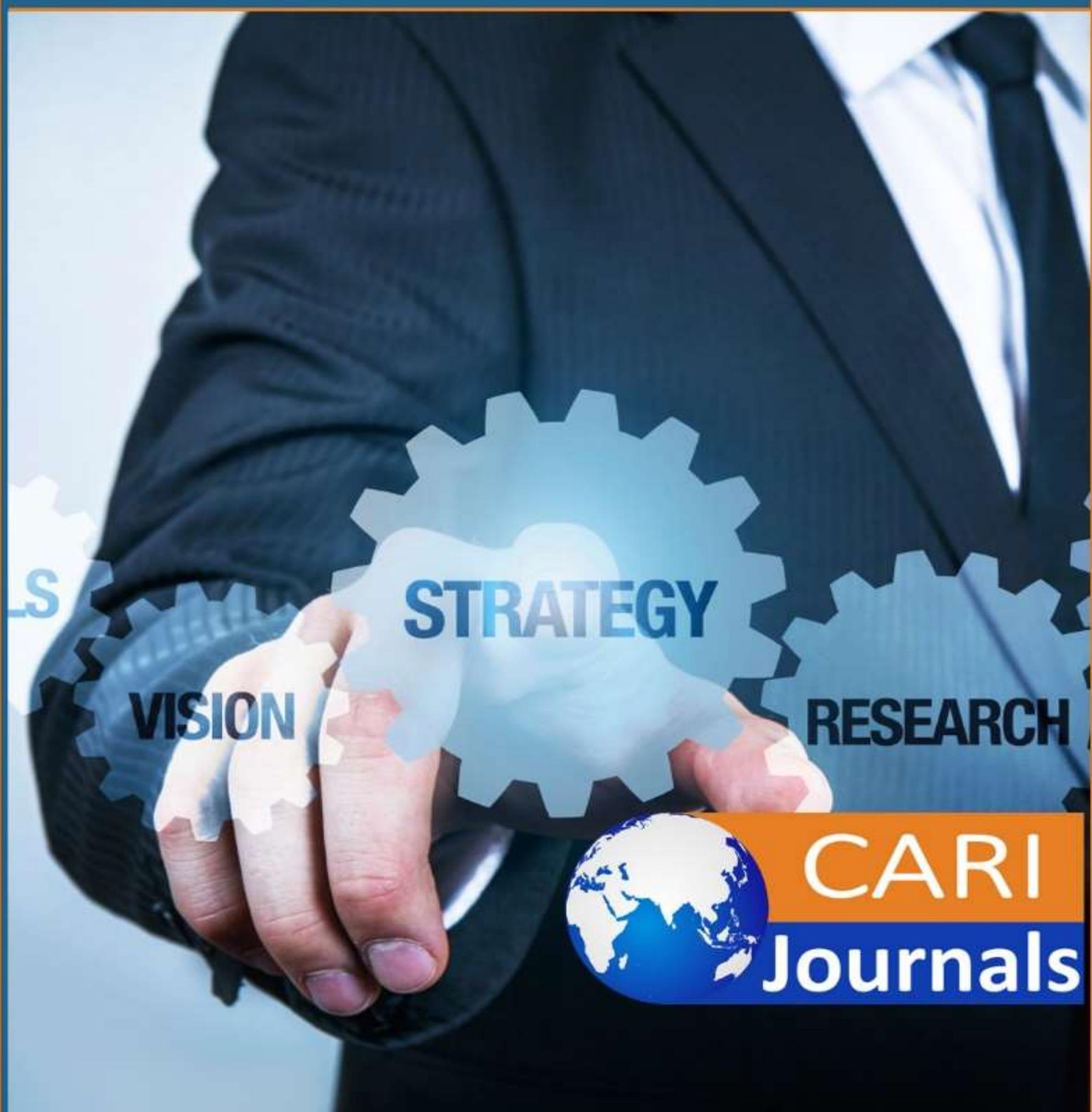


Journal of Business and Strategic Management

ISSN 2520-0402 (Online)

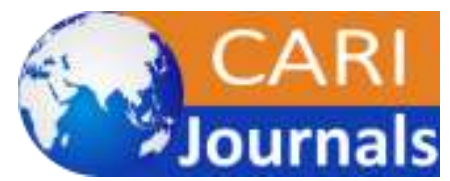

Vol.6, Issue No. 3, pp 57-81, 2021

www.carijournals.org

\title{
Influence of Monitoring and Evaluation System Components on the Performance of National Non-Governmental Organizations (NNGOs): A Case of Global Aim Uganda
}

\author{
$1 *$ Isaac Eremugo \\ Post Graduate Student, School of Humanities and Social Sciences \\ Uganda Technology and Management University (UTAMU) \\ *Corresponding Author's E-mail: eremugonatal@gmail.com \\ ${ }^{2}$ Dr. John Micheal Maxel Okoche \\ Lecturer and Dean, School of Humanities and Social Sciences \\ Uganda Technology and Management University (UTAMU)
}

\begin{abstract}
Purpose: The purpose of this study was to examine the influence of Monitoring and Evaluation (M\&E) system components on the performance of National Non-Governmental Organizations (NNGOs) in Uganda: A case of Global Aim Uganda. The study focused on the i) influence of organizational structure on the performance of Global Aim Uganda (GAU), ii) influence of routine $M \& E$ on the performance of GAU and the influence of utilization of M\&E information on the performance of GAU.

Methodology: The study used a cross sectional study design employing both qualitative and quantitative research approaches. The population of the study consisted of the staff of Global Aim Uganda, implementing partners and project beneficiaries to which stratified random sampling was applied. 164 respondents (100\% response rate) were reached for the survey and 15 respondents out of 17 (88.23\% response rate) were reached for interviews. Qualitative data were collected using interview guides analyzed using content analysis and presented as text in normative form. Quantitative data was collected using researcher administered questionnaires. Responses were rated on a 5-Likert scale and were coded, cleaned and analyzed for descriptive and inferential statistic using SPSS software (version 20.0) presented in tables.

Findings: Correlational analysis showed a significant and positive correlation between performance of Global Aim Uganda and organizational structure $\left(\mathrm{r}=.244^{* *}, \mathrm{p}=.002,<0.05\right)$, routine $\mathrm{M} \& \mathrm{E}\left(\mathrm{r}=.403^{* *}, \mathrm{p}=.000,<0.01\right)$ and utilization of $\mathrm{M} \& \mathrm{E}$ information $\left(\mathrm{r}=.526^{* *}, \mathrm{p}=.000\right.$, $<0.01$ ). Results from regression analysis revealed a non-significant and negative influence of organizational structure $(\beta=-.013, p=.873,>0.05)$ on performance. While, there is a positive and significant influence of routine $\mathrm{M} \& \mathrm{E}(\beta=.199, \mathrm{p}=.001,<0.05)$ and utilization of $\mathrm{M} \& \mathrm{E}$ information $(\beta=.327, p=.000,<0.05)$ on the performance. The coefficient of determination $\left(\mathrm{r}^{2}\right)$ between predictor variables and performance of Global Aim Uganda is $0.322(32.2 \%)$.
\end{abstract}


Journal of Business and Strategic Management

ISSN 2520-0402 (Online)

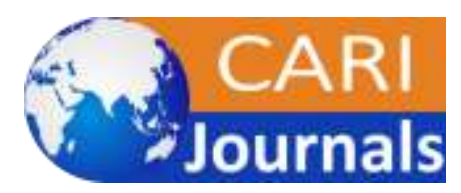

Vol.6, Issue No. 3, pp 57-81, 2021

www.carijournals.org

Unique contribution to theory, practice and policy: There is need to strengthen the M\&E system components. These can be done through improved internal reporting, broadening the functions of the $M \& E$ unit, incorporating aspects of $M \& E$ in staff roles and responsibilities, conducting project specific baseline surveys, starting to conduct project evaluations and increasing the utilization of M\&E information in decision making. Further study should focus on the M\&E capacity of the organization.

Key words: Organizational structure, routine monitoring and evaluation, utilization of $M \& E$ information, performance

\subsection{INTRODUCTION}

\subsection{Background}

Non-Governmental Organizations (NGOs) play a vital role in supplementing government efforts in the delivery of goods and social services especially in the developing countries (Owa et al., 2017). Martens (2002) defined NGOs as formal independent societal organizations whose primary aim is to promote common goals at the national or the international level. NGOs came to prominence after the Second World War (1939-1945). According to Lutabingwa et al. (1997), NGOs in Africa emerged more strongly in the 1980s when donors started to shift some of their funds from governments to civil society. In Uganda, the NGO sector gained importance in the 1970s and 1980s following the collapse of the government (Barr et al., 2003). Since the 1950s, donors have increasingly channeled a lot of funds in form of development assistance to NGOs to carry out life changing interventions in areas such as livelihood, nutrition, environment, governance, human rights and rule of law among others globally (Owa et al., 2017).

The growth of the NGO sector partly reflects the frustration of donors with African governments who have become corrupt, ineffective and inefficient (Owa et al., 2017). Availability of donor funds has also led to explosion in the number of NGOs. For example, the number of registered NGOs in Uganda has grown from less than 500 in 1992 to 3,500 in 2002 and close to 7,000 in 2008 (Bougheas et al., 2012). Despite the increase in the number of NGOs and funding to the sector, the performance of the NGOs on the ground have been questioned by stakeholders with $25 \%$ of the population in Uganda still living below poverty line (Omona \& Mukuye, 2013).

Samsonowa (2012) defined performance as the level of goal achievement by an organization. Organizational performance can be measured by the relevance, effectiveness, efficiency, impact and quality of the intervention (Ghalem et al., 2016). Reports have indicated that NGOs have poor level of performance characterized by high project failure rates associated with poor quality of work, massive corruption of donor funds and poor accountability (Barr et al., 2003; Jones, 2013). The poor performance of NGOs is an impediment to achieving Uganda Vision 2040 and the Sustainable Development Goals (SDGs). There has been a general demand from stakeholders for NGOs to demonstrate the results of their work and show accountability (Lenfant \& Rutten, 2013).

The need to improve performance by demonstrating results and showing accountability for donor funds resulted into the introduction of donor led Monitoring and Evaluation (M\&E) systems (Mueller-Hirth, 2012a; Porter \& Goldman, 2013). A monitoring and evaluation system is one in which M\&E is a regular part of the project life cycle. (Masuku \& Ijeoma, 2015) defined monitoring 
Journal of Business and Strategic Management

ISSN 2520-0402 (Online)

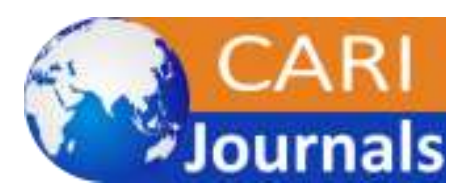

Vol.6, Issue No. 3, pp 57-81, 2021

www.carijournals.org

as a process of continuous collection and analysis of data on an ongoing project, program or policy to provide management and other stakeholders on progress towards achieving predetermined objectives and goals. While, evaluation was defined as the systematic and periodic assessment of an on-going or a completed project, program or policy, in relation to its design, implementation and results based on specified criteria.

However, the introduction of donor led M\&E system has not entirely achieved its purpose. This is because the M\&E system have been simply used to meet donor requirements (Biwott et al., 2017). While the system suffers from limited organizational capacities and lack of management support characterized by limited commitment of resources and utilization of M\&E information (Holvoet \& Inberg, 2015). To reduce the challenges, some donors have been carrying out capacity building and allocation of specific funds for M\&E (Mueller-Hirth, 2012).

Few studies examined the influence of M\&E system components on the performance of NonGovernmental Organizations in Uganda (Kasule, 2016; Nasambu, 2016; Okeny, 2015). However, limited studies have been devoted to the evaluation of the influence of M\&E system components on the performance of National Non-Governmental Organizations (NNGOs) in Uganda. This study examined the influence of M\&E system components on the performance of Global Aim Uganda. Global Aim Uganda is a NNGOs operating in Adjumani District of West Nile region, Uganda. It was selected for this study because of its expensive experience in implementing donor led projects among refugees and the host communities in District.

\subsection{Statement of the problem}

Monitoring and Evaluation (M\&E) system are critical for improved organizational performance (Muller-Hirth, 2012). Global Aim Uganda had put in place a monitoring and evaluation systems that was based on the terms and conditions of each donor to improve performance. Yet still only half $(50 \%)$ of the NGO's beneficiaries in Adjumani district were satisfied with the organizational performance according to a survey conducted in 2015 (UBOS, 2016). In a bid to improve performance, Global Aim Uganda in partnership with Stromme Foundation Uganda has established a Performance Tracker in 2019 to improve the efficiency, effectiveness, impact and sustainability of its interventions, recruited and oriented staff, among other strategies. Yet it is not clear how the new M\&E systems influenced the performance of Global Aim Uganda since it was introduced.

Several studies have focused on monitoring and evaluation systems and performance of Nongovernment organizations internationally (Mueller-Hirth, 2012b; Sulemana et al., 2018; Wongtschowski et al., 2016) and in Uganda (Nasambu, 2016; Kasule, 2016; Okeny, 2015). However, these have not adequately examined the influence of M\&E system components such as organizational structure, routine $M \& E$ and utilization of $M \& E$ information on the performance of Global Aim Uganda. Therefore, this study examined the influence of organizational structure, routine $\mathrm{M} \& \mathrm{E}$ and the utilization of $\mathrm{M} \& \mathrm{E}$ information on the performance of Global Aim Uganda.

\subsection{Purpose of the study}

To examine the influence of monitoring and evaluation system components on the performance of Global Aim Uganda 
Journal of Business and Strategic Management

ISSN 2520-0402 (Online)

Vol.6, Issue No. 3, pp 57-81, 2021

www.carijournals.org

\subsection{Specific objectives}

1) To evaluate the influence of organizational structure on the performance of Global Aim Uganda.

2) To assess the influence of routine monitoring and evaluation on the performance of Global Aim Uganda.

3) To examine the influence of the utilization of $M \& E$ information on the performance of Global Aim Uganda

\subsection{Research questions}

1) What is the influence of organizational structure on the performance of Global Aim Uganda?

2) What is the influence of routine $M \& E$ on the performance of Global Aim Uganda?

3) What is the influence of the utilization of $M \& E$ information on the performance of Global Aim Uganda?

\subsection{Conceptual Framework}

The conceptual framework (Figure 1) presents the relationship between the independent and dependent variables of the study. The independent variables are the components of the M\&E system (organizational structure with $M \& E$ functions, routine monitoring and evaluation and utilization of M\&E information) that influence the performance of Global Aim Uganda (dependent variable) (Gorgens \& Kusek, 2009).

\section{INDEPENDENT VARIABLES}

(M\&E System Components)

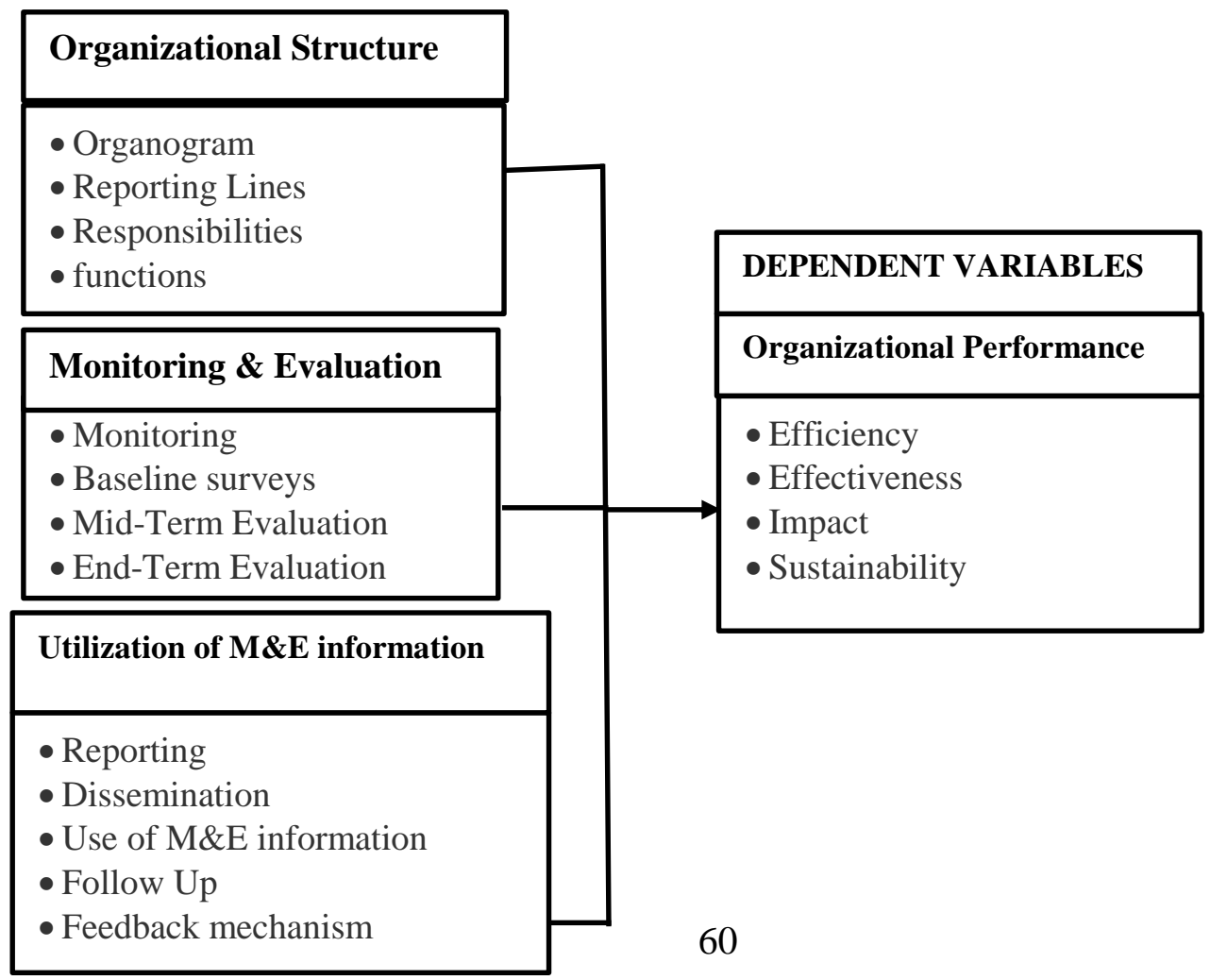


Journal of Business and Strategic Management

ISSN 2520-0402 (Online)

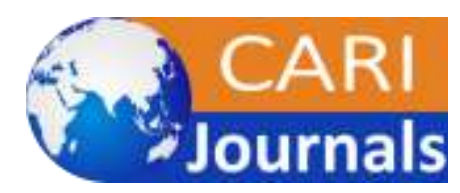

Vol.6, Issue No. 3, pp 57-81, 2021

www.carijournals.org

Figure 1. Conceptual framework modified from Gorgens and Kusek (2009).

\subsection{LITERATURE REVIEW}

\subsection{System Theory}

The study was guided by the system theory which was developed by (von Bertalanffy, 1968). In his book the "general system theory", von Bertalanffy emphasized the consideration of the organism as a whole or system analogous to an organization at its various parts. The system theory is based on the fact that a system consists of elements standing in interrelations and these elements cannot function independently. The earlier philosophers such as Aristotle also advocated for thinking about things in whole not parts (Cordon, 2013). According to Aristotle, the whole is composed of many parts but the whole and the many parts are not the same. This is because a biophysical system may be more than the sum of its parts if it expresses synergy or emergent behavior (Nikolaev \& Fortin, 2020). Modern application of system theory started after the Second World War where policy changes in one country had ripple effects on others (Arnold \& Wade, 2015). The system theory has been applied in the fields of social and natural sciences such as management (Meles et al., 2010), physics (Sayin, 2016), and Engineering (Nikolaev \& Fortin, 2020) among others.

A system can be either open or closed (Meles et al., 2010; Sayin, 2016). An open system allows interaction between its internal components and the environment. A closed system is where the internal components are isolated from the environment. Most organizations fall under the open system as its components regularly interact with the external environment. System theory enables us to apply the holistic approach in understanding the functioning of organizations by examining the influence of the different input components such as man power, finances and management support on outputs.

The system theory has been critiqued because of limited attention given to intersystem relationship. The theory is theoretically legitimate but too abstract for practical application because it lacks a clear step by step implementation strategy which calls into question its utilitarian value (Goldstein, 1975). "A prerequisite to the ability to manage the abstract nature of systems theory is a willingness to accept that knowing does not have definable boundaries" (Goldstein, 1975).

\subsection{Empirical studies}

Table 1 presents the empirical literature review and the identified gaps

Table 1. Empirical literature review and gap

\begin{tabular}{|l|l|l|l|l|}
\hline Variable & Author & Findings & Knowledge Gap & Focus of current study \\
\hline $\begin{array}{l}\text { Organizational } \\
\text { structure }\end{array}$ & $\begin{array}{l}\text { Ajabe et al. } \\
(2016)\end{array}$ & $\begin{array}{l}\text { Organizational } \\
\text { structure had } \\
\text { significant } \\
\text { impact on }\end{array}$ & $\begin{array}{l}\text { Used secondary } \\
\text { sources of data }\end{array}$ & $\begin{array}{l}\text { Study influence of } \\
\text { organizational structure } \\
\text { on performance using } \\
\text { primary sources of data }\end{array}$ \\
\hline
\end{tabular}


Vol.6, Issue No. 3, pp 57-81, 2021

\begin{tabular}{|c|c|c|c|c|}
\hline & & $\begin{array}{l}\text { organizational } \\
\text { performance }\end{array}$ & & \\
\hline & $\begin{array}{l}\text { Nasambu } \\
(2015)\end{array}$ & $\begin{array}{l}\text { M\&E } \\
\text { structure had a } \\
\text { significant } \\
\text { correlation } \\
\text { with the } \\
\text { performance } \\
\text { of M\&E } \\
\text { system }\end{array}$ & $\begin{array}{l}\text { The study focused } \\
\text { on the influence of } \\
\text { organizational } \\
\text { structure on the } \\
\text { performance of the } \\
\text { M\&E system using } \\
\text { quantitative } \\
\text { approach. The } \\
\text { respondents were } \\
\text { staff of NGOs }\end{array}$ & $\begin{array}{l}\text { Influence of } \\
\text { organizational structure } \\
\text { on the performance of } \\
\text { the organization using } \\
\text { both qualitative and } \\
\text { quantitative approach. } \\
\text { The respondents were } \\
\text { staff, partners and } \\
\text { beneficiaries of Global } \\
\text { Aim Uganda }\end{array}$ \\
\hline & $\begin{array}{l}\text { Muller- } \\
\text { Hirth } \\
\text { (2012) }\end{array}$ & $\begin{array}{l}\text { The } \\
\text { organizational } \\
\text { structure did } \\
\text { not support } \\
\text { the collection } \\
\text { of additional } \\
\text { data nor used } \\
\text { collected data } \\
\text { for improving } \\
\text { organizational } \\
\text { performance. }\end{array}$ & $\begin{array}{l}\text { Used qualitative } \\
\text { research to assess } \\
\text { the impact of } \\
\text { organizational } \\
\text { culture on the } \\
\text { performance of } \\
\text { Non-Governmental } \\
\text { Organizations } \\
\text { (NGOs) in South } \\
\text { Africa }\end{array}$ & $\begin{array}{l}\text { The present study used } \\
\text { both qualitative and } \\
\text { quantitative approach to } \\
\text { assess the influence of } \\
\text { M\&E on the } \\
\text { performance of National } \\
\text { Non-Governmental } \\
\text { Organizations (NNGOs) } \\
\text { in Uganda }\end{array}$ \\
\hline \multirow[t]{2}{*}{ Routine $\mathrm{M} \& \mathrm{E}$} & $\begin{array}{l}\text { Porter and } \\
\text { Goldman } \\
\text { (2013) and } \\
\text { Holvoet } \\
\text { and Inberg } \\
\text { (2015) }\end{array}$ & $\begin{array}{l}\text { Weak demand } \\
\text { for } \mathrm{M} \& \mathrm{E} \\
\text { information. }\end{array}$ & $\begin{array}{l}\text { Monitoring is being } \\
\text { confused with } \\
\text { evaluation }\end{array}$ & $\begin{array}{l}\text { To find out if the } \\
\text { organization conducts } \\
\text { both monitoring and } \\
\text { evaluation, how they } \\
\text { influence organizational } \\
\text { performance }\end{array}$ \\
\hline & $\begin{array}{l}\text { Biwott et } \\
\text { al. }(2017)\end{array}$ & $\begin{array}{l}\text { M\&E was } \\
\text { done mainly } \\
\text { to meet donor } \\
\text { demands with } \\
\text { limited } \\
\text { appetite for } \\
\text { data } \\
\text { utilization }\end{array}$ & $\begin{array}{l}\text { The study used } \\
\text { documentary } \\
\text { review to assess the } \\
\text { influence of } \mathrm{M} \& \mathrm{E} \\
\text { on project } \\
\text { sustainability }\end{array}$ & $\begin{array}{l}\text { The study focused on } \\
\text { the influence of M\&E } \\
\text { on efficiency, } \\
\text { effectiveness, impact \& } \\
\text { sustainability }\end{array}$ \\
\hline
\end{tabular}


Journal of Business and Strategic Management

ISSN 2520-0402 (Online)

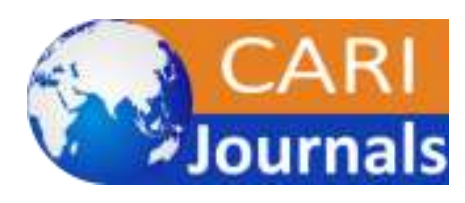

Vol.6, Issue No. 3, pp 57-81, 2021

$\underline{\text { www.carijournals.org }}$

\begin{tabular}{|l|l|l|l|l|}
\hline $\begin{array}{l}\text { Utilization of } \\
\text { infermation }\end{array}$ & $\begin{array}{l}\text { Holvoet } \\
\text { and Inberg } \\
(2015)\end{array}$ & $\begin{array}{l}\text { The study } \\
\text { found that } \\
\text { utilization of } \\
\text { M\&E } \\
\text { information } \\
\text { was very } \\
\text { limited }\end{array}$ & $\begin{array}{l}\text { Conducted a } \\
\text { documentary } \\
\text { review and semi- } \\
\text { structured interview } \\
\text { on the "diagnostic } \\
\text { assessment of the } \\
\text { Uganda's education } \\
\text { sector M\&E } \\
\text { system" }\end{array}$ & $\begin{array}{l}\text { Study the influence of } \\
\text { utilization of M\&E } \\
\text { information in National } \\
\text { Non-Governmental } \\
\text { Organizations using } \\
\text { both qualitative and } \\
\text { quantitative primary } \\
\text { data }\end{array}$ \\
\hline
\end{tabular}

\subsection{METHODOLOGY}

The study used a cross sectional study design employing both qualitative and quantitative research approaches and interviews and survey data collection methods, respectively. The study population (278) for the quantitative approach consisted of the staff of Global Aim Uganda (16), implementing partners (22) and project beneficiaries (240). The sample size for the study was determined using the formulae of Yamane (1967). Sampling was done using stratified random sampling method. Under this method, sampling proportionate to size was used based on the three strata of Global Aim Uganda staff, implementing partners and project beneficiaries. The study participants were then selected using simple random sampling techniques within each respective stratum. Quantitative data was collected using researcher administered questionnaires; responses were rated on a 5-Likert scale and were coded, cleaned and analyzed for descriptive and inferential statistic using SPSS software (version 20.0). First, the questionnaires were pretested using 10 respondents who didn't participate in the final study. A value of .70 for internal consistency of the questionnaire was obtained using Chronbach's alpha co-efficient. Data was then collected from the determined sample of staff of Global Aim Uganda (9), implementing partners (13) and project beneficiaries (142) and presented in tables.

Qualitative data was collected using key informant interview guides from 17 key informants that consisted of staff of Global Aim Uganda, local leaders and other implementing partners. The qualitative data were analyzed using content analysis and presented as text in normative form. Both quantitative and qualitative data were collected while observing ethical consideration of privacy, ambiguity, informed consent and voluntary participation of the respondents.

\subsection{PRESENTATION, ANALYSIS AND INTERPRETATION OF FINDINGS}

\subsection{Response Rate}

This study used both researchers administered questionnaires and key informant interview guide (KIIG) as data collection tool. The response rate of the respondents is presented in Table 2.

Table 2. Response rate of the respondents

\begin{tabular}{|l|l|l|l|}
\hline Tool & Response & Frequency & Percentage $(\%)$ \\
\hline
\end{tabular}


Journal of Business and Strategic Management

ISSN 2520-0402 (Online)

$\underline{\text { www.carijournals.org }}$

Vol.6, Issue No. 3, pp 57-81, 2021

\begin{tabular}{|l|l|l|l|}
\hline Questionnaire & Returned & 164 & 100 \\
\hline & Unreturned & 164 & 100 \\
\hline KIIG & Returned & 15 & 88.23 \\
\hline & Unreturned & 2 & 11.77 \\
\hline
\end{tabular}

Result in Table 2 indicates that all the targeted 164 respondents of the different categories (staff, beneficiaries and partners) were administered the questionnaire resulting into a $100 \%$ response rate. The high response rate was because the project beneficiaries were mainly in established groups that made mobilization easy. A response rate of $88.23 \%$ was obtained from the key informants as 15 participants were administered the key informants interview guide out of the targeted 17 participants. The response rate $(88.23 \%$ ) was considered to be good for the study as a response rate of $60 \%$ and above was considered satisfactory for survey studies (Fincham, 2008).

\subsection{Organizational structure and performance of Global Aim Uganda}

The responses of the study participants on the statements related to the influence of organizational structure on the performance of Global Aim Uganda (GAU) were rated on a 5-Likert scale where: 1 - Strongly Disagreed (SD), 2 - Disagreed (D), 3 - Not sure (N), 4 - Agreed (A) and 5 - Strongly Agreed (SA). The extents to which the respondents agreed or disagreed with the statements were presented in the Table 3.

Table 3. Descriptive statistics for organizational structure at Global Aim Uganda

\begin{tabular}{|c|c|c|c|c|c|c|c|}
\hline Statements & SD & D & NS & A & SA & Mean & Stdev \\
\hline $\begin{array}{l}\text { Organogram influences } \\
\text { project performance }\end{array}$ & $\begin{array}{r}1 \\
(0.6 \%)\end{array}$ & $\begin{array}{r}1 \\
(0.6 \%)\end{array}$ & & $\begin{array}{r}115 \\
(70.1 \%)\end{array}$ & $\begin{array}{r}47 \\
(28.7 \%)\end{array}$ & 4.26 & 0.55 \\
\hline $\begin{array}{l}\text { Reporting lines influences } \\
\text { project performance }\end{array}$ & & $\begin{array}{r}1 \\
(0.6 \%)\end{array}$ & $\begin{array}{r}1 \\
(0.6 \%)\end{array}$ & $\begin{array}{r}78 \\
(47.6 \%)\end{array}$ & $\begin{array}{r}84 \\
(51.2 \%)\end{array}$ & 4.49 & 0.55 \\
\hline $\begin{array}{l}\text { Clearly defined staff } \\
\text { responsibilities influences } \\
\text { project performance }\end{array}$ & $\begin{array}{r}1 \\
(0.6 \%)\end{array}$ & & $\begin{array}{r}2 \\
(1.2 \%)\end{array}$ & $\begin{array}{r}59 \\
(36.0 \%)\end{array}$ & $\begin{array}{r}102 \\
(62.2 \%)\end{array}$ & 4.59 & 0.58 \\
\hline $\begin{array}{l}\text { Functions of the M\&E unit } \\
\text { influences project } \\
\text { performance }\end{array}$ & $\begin{array}{r}6 \\
(3.7 \%)\end{array}$ & $\begin{array}{r}2 \\
(1.2 \%)\end{array}$ & $\begin{array}{r}1 \\
(0.6 \%)\end{array}$ & $\begin{array}{r}112 \\
(68.2 \%)\end{array}$ & $\begin{array}{r}43 \\
(26.2 \%)\end{array}$ & 4.12 & 0.80 \\
\hline $\begin{array}{l}\text { GAU has an organogram } \\
\text { with M\&E unit }\end{array}$ & $\begin{array}{r}8 \\
(4.9 \%)\end{array}$ & $\begin{array}{r}2 \\
(1.2 \%)\end{array}$ & $\begin{array}{r}1 \\
(0.6 \%)\end{array}$ & $\begin{array}{r}113 \\
(68.9 \%)\end{array}$ & $\begin{array}{r}40 \\
(24.4 \%)\end{array}$ & 4.07 & 0.86 \\
\hline
\end{tabular}


Journal of Business and Strategic Management

ISSN 2520-0402 (Online)

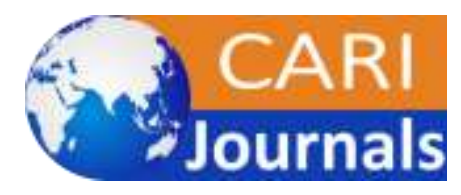

Vol.6, Issue No. 3, pp 57-81, 2021

$\underline{\text { www.carijournals.org }}$

\begin{tabular}{|c|c|c|c|c|c|c|c|}
\hline $\begin{array}{l}\text { GAU has a clear reporting } \\
\text { line }\end{array}$ & $\begin{array}{r}2 \\
(1.2 \%)\end{array}$ & $\begin{array}{r}1 \\
(0.6 \%)\end{array}$ & $\begin{array}{r}2 \\
(1.2 \%)\end{array}$ & $\begin{array}{r}85 \\
(51.8 \%)\end{array}$ & $\begin{array}{r}74 \\
(45.1 \%)\end{array}$ & 4.39 & 0.67 \\
\hline $\begin{array}{l}\text { Staff have clearly defined } \\
\text { responsibilities }\end{array}$ & & & & $\begin{array}{r}68 \\
(41.5 \%)\end{array}$ & $\begin{array}{r}96 \\
(58.5 \%)\end{array}$ & 4.59 & 0.49 \\
\hline $\begin{array}{l}\text { M\&E unit have clearly } \\
\text { defined functions }\end{array}$ & $\begin{array}{r}1 \\
(0.6 \%)\end{array}$ & $\begin{array}{r}5 \\
(3.0 \%)\end{array}$ & $\begin{array}{r}1 \\
(0.6 \%)\end{array}$ & $\begin{array}{r}91 \\
(55.5 \%)\end{array}$ & $\begin{array}{r}66 \\
(40.2 \%)\end{array}$ & 4.32 & 0.70 \\
\hline Mean & & & & & & 4.35 & 0.65 \\
\hline
\end{tabular}

The study findings in Table 3 indicated that $162(98.8 \%)$ of the respondents agreed that organogram influences project performance as opposed to $2(1.2 \%)$ who disagreed. The mean of 4.26 and standard deviation of 0.55 implies that most respondents were in agreement that organogram influences project performance.

The study found that $162(98.8 \%)$ of the respondents agreed that reporting lines influences project performance, $2(1.2 \%)$ disagreed and $1(0.6 \%)$ was not sure. With a mean of 4.49 and standard deviation of 0.55 , the result indicated that most respondents agreed that reporting lines influences project performance. This result showed that clear reporting lines if developed and used can influence the performance of Global Aim Uganda.

The study indicated that $161(98.2 \%)$ of the respondents agreed that clearly defined staff roles and responsibilities can influence project performance, $1(0.6 \%)$ disagreed while $2(1.2 \%)$ were not sure. The mean of 4.59 and standard deviation of 0.58 showed that majority of the respondents agreed that clearly defined staff roles and responsibilities influences project performance. This implies that staff roles and responsibilities if properly defined can influence project performance at Global Aim Uganda.

It was established that $155(94.4 \%)$ of the respondents agreed that the functions of the M\&E unit influences project performance, $8(4.9 \%)$ disagreed) and $1(0.6 \%)$ were not sure. The mean of 4.12 and standard deviation of 0.80 implies that almost every respondent agreed that M\&E unit function influences project performance. The few who disagreed or were not sure were most likely new beneficiaries, old beneficiaries who didn't attend any monitoring or feedback meetings. The study implies that M\&E functions if clearly defined and implemented well will most likely improve the performance of Global Aim Uganda.

The study reported that $153(93.3 \%)$ of the respondents agreed that Global Aim Uganda has an organogram with M\&E unit, $10(6.1 \%)$ disagreed and $1(0.6 \%)$ were not sure. The mean of 4.07 and standard deviation of 0.86 implies that most of the respondents were aware that Global Aim Uganda has an organogram with M\&E unit. The few who did not know or were not sure if Global Aim Uganda have an organogram with $M \& E$ unit could be new beneficiaries or partners who never visited the Global Aim office. Having an organogram shows that the organization has a framework for reporting, delegation of authority, segregation of roles and responsibilities. 
Journal of Business and Strategic Management

ISSN 2520-0402 (Online)

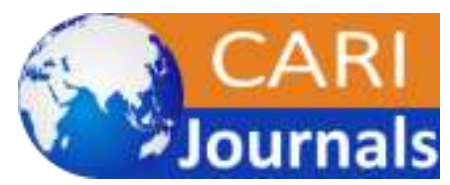

Vol.6, Issue No. 3, pp 57-81, 2021

www.carijournals.org

The responses showed that $159(96.9 \%)$ of the respondents agreed that there is a clear reporting line, $3(1.8 \%)$ disagreed and $2(1.2 \%)$ were not sure. The mean of 4.39 and standard deviation of 0.67 implies that majority of the respondents were in agreement that Global Aim Uganda had a clear reporting line. In agreement with the statement one of the KIs said.

"We report any issue concerning the vegetables that we grow to our group chairperson who in turn channels the information to the Community Based Facilitator (CBF) who communicates directly with the project staff".

The study found that all164 (100\%) respondents agreed that staff at Global Aim Uganda had a clearly defined responsibilities with a mean value of 4.59 and standard deviation of 0.49 . This implied that the Global Aim staff performed up to the expectation of the respondents in their various capacities. It also showed that the respondents were able to know who to contact in times of need.

The study reported that $157(95.7 \%)$ respondents agreed that M\&E unit had a clearly defined functions $6(3.6 \%)$ disagreed while $1(0.6 \%)$ were not sure. The mean of 4.32 and standard deviation of 0.70 , the respondents generally agreed that the M\&E unit had clearly defined functions. The respondents who were not sure or disagreed could probably be the members of staff, beneficiaries or partners who never interfaced or read the functions of the M\&E unit. However, even among the KIs, some members were not clear about the functions of the M\&E unit as it was only limited to monitoring as reported below.

"I think the function of the $M \& E$ unit is to only monitor and report on the progress of the project. We have never been trained by the M\&E unit".

\subsubsection{Routine monitoring and evaluation and performance of Global Aim Uganda}

The responses of the study participants on the statements related to the influence of routine M\&E on the performance of Global Aim Uganda (GAU) were rated on a 5-Likert scale where: 1 Strongly Disagreed (SD), 2 - Disagreed (D), 3 - Not sure (N), 4 - Agreed (A) and 5 - Strongly Agreed (SA). The extents to which the respondents agreed or disagreed with the statements were presented in the Table 4.

Table 4. Descriptive statistics for routine monitoring and evaluation at Global Aim Uganda

\begin{tabular}{|l|r|r|r|r|r|r|r|}
\hline Statements & SD & D & NS & A & SA & Mean & Stdev \\
\hline $\begin{array}{l}\text { Routine monitoring } \\
\text { influences project } \\
\text { performance }\end{array}$ & 1 & & & & & & \\
\hline $\begin{array}{l}\text { Baseline surveys influences } \\
\text { project performance }\end{array}$ & $(0.6 \%)$ & & $\begin{array}{r}73 \\
(44.5 \%)\end{array}$ & $\begin{array}{r}(54.9 \%) \\
(1.8 \%)\end{array}$ & $\begin{array}{r}80.53 \\
(48.8)\end{array}$ & 0.57 \\
\hline
\end{tabular}


Journal of Business and Strategic Management

ISSN 2520-0402 (Online)

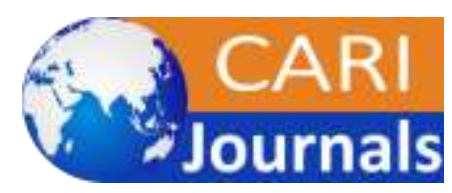

Vol.6, Issue No. 3, pp 57-81, 2021

$\underline{\text { www.carijournals.org }}$

\begin{tabular}{|c|c|c|c|c|c|c|c|}
\hline $\begin{array}{l}\text { Mid-term evaluation } \\
\text { influences project } \\
\text { performance }\end{array}$ & $\begin{array}{r}7 \\
(4.3 \%)\end{array}$ & $\begin{array}{r}3 \\
(1.8 \%)\end{array}$ & $\begin{array}{r}1 \\
(0.6 \%)\end{array}$ & $\begin{array}{r}140 \\
(85.4 \%)\end{array}$ & $\begin{array}{r}13 \\
(7.9 \%)\end{array}$ & 3.91 & 0.73 \\
\hline $\begin{array}{l}\text { End-Term evaluation } \\
\text { influences project } \\
\text { performance }\end{array}$ & $\begin{array}{r}7 \\
(4.3 \%)\end{array}$ & $\begin{array}{r}2 \\
(1.2 \%)\end{array}$ & $\begin{array}{r}2 \\
(1.2 \%)\end{array}$ & $\begin{array}{r}137 \\
(83.5 \%)\end{array}$ & $\begin{array}{r}16 \\
(9.8 \%)\end{array}$ & 3.93 & 0.74 \\
\hline $\begin{array}{l}\text { Global Aim Uganda } \\
\text { conducts routine monitoring } \\
\text { of all projects }\end{array}$ & $\begin{array}{r}7 \\
(4.3 \%)\end{array}$ & $\begin{array}{r}1 \\
(0.6 \%)\end{array}$ & $\begin{array}{r}3 \\
(1.8 \%)\end{array}$ & $\begin{array}{r}50 \\
(30.5 \%)\end{array}$ & $\begin{array}{r}103 \\
(62.8 \%)\end{array}$ & 4.47 & 0.92 \\
\hline $\begin{array}{l}\text { Global Aim Uganda } \\
\text { conducts baseline surveys for } \\
\text { all projects }\end{array}$ & $\begin{array}{r}37 \\
(22.6 \%)\end{array}$ & $\begin{array}{r}6 \\
(3.7 \%)\end{array}$ & $\begin{array}{r}1 \\
(0.6 \%)\end{array}$ & $\begin{array}{r}43 \\
(26.2 \%)\end{array}$ & $\begin{array}{r}77 \\
(47.0 \%)\end{array}$ & 3.71 & 1.61 \\
\hline $\begin{array}{l}\text { Global Aim Uganda } \\
\text { conducts Mid-Term } \\
\text { evaluations for all projects }\end{array}$ & $\begin{array}{r}152 \\
(92.7 \%)\end{array}$ & $\begin{array}{r}4 \\
(2.4 \%)\end{array}$ & $\begin{array}{r}1 \\
(0.6 \%)\end{array}$ & $\begin{array}{r}6 \\
(3.7 \%)\end{array}$ & $\begin{array}{r}1 \\
(0.6 \%)\end{array}$ & 1.17 & 0.67 \\
\hline $\begin{array}{l}\text { Global Aim Uganda } \\
\text { conducts End-Term } \\
\text { evaluations for all projects }\end{array}$ & $\begin{array}{r}151 \\
(92.1 \%)\end{array}$ & $\begin{array}{r}5 \\
(3.0 \%)\end{array}$ & $\begin{array}{r}4 \\
(2.4 \%)\end{array}$ & $\begin{array}{r}2 \\
(1.2 \%)\end{array}$ & $\begin{array}{r}2 \\
(1.2 \%)\end{array}$ & 1.16 & 0.64 \\
\hline Mean & & & & & & 3.42 & 0.80 \\
\hline
\end{tabular}

The results from Table 4 showed that 163 (99.4\%) of the respondents agreed that routine M\&E influences project performance at Global Aim Uganda and $1(0.6 \%)$ disagreed. The mean of 4.53 and standard deviation of 0.57 implies that the respondents generally agreed that routine M\&E influences project performance. This shows that routine $\mathrm{M} \& \mathrm{E}$ if properly conducted could influence the performance of Global Aim Uganda.

The study found that $161(98.2 \%)$ of the respondents agreed that baseline surveys influences project performance while, $3(1.8 \%)$ were not sure. The mean of 4.48 and standard deviation of 0.54 implies that most respondents were in agreement with the statement that baseline surveys influences project performance. This implies that baseline surveys if properly done will influence the project performance at Global Aim Uganda.

The study reported that $153(93.3 \%)$ of the respondents agreed that mid-term evaluation influences project performance, $10(6.1 \%)$ disagreed and $1(0.6 \%)$ were not sure. The mean was 3.91 and standard deviation was 0.73 which implies that majority of the respondents mainly agreed with the statement that mid-term evaluation influences project performance. The study indicated that midterm evaluation is well conducted can influence the performance of projects at Global Aim Uganda. 
Journal of Business and Strategic Management

ISSN 2520-0402 (Online)

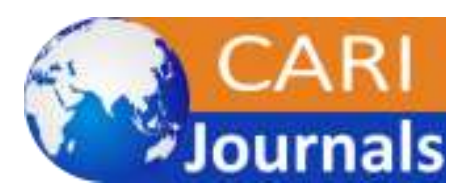

Vol.6, Issue No. 3, pp 57-81, 2021

www.carijournals.org

The study showed that $153(93.3 \%)$ of the respondents agreed that end-term evaluation influences project performance, $9(5.5 \%)$ disagreed and $2(1.2 \%)$ were not sure. The mean was 3.93 and standard deviation was 0.74 which implies that majority of the respondents mainly agreed with the statement that end-term evaluation influences project performance. The study indicated that endterm evaluation is well conducted can influence the performance of projects at Global Aim Uganda.

Results showed that $153(93.3 \%)$ of the study participants agreed that Global Aim Uganda conducts routine $\mathrm{M}, 8(4.9 \%)$ disagreed and $3(1.8 \%)$ were not sure. The mean was 4.47 and standard deviation was 0.92 which implies that the respondents generally agreed with the statement that Global Aim Uganda conducts routine $M$ of its projects. This was confirmed by one of the staff.

"As the M\&E Officer I conduct monitoring visits once a month. However, project staffs are also involved in monitoring as they go to the field to do their daily activities. They help in data collection from the beneficiaries and reporting".

The study found that $120(73.2 \%)$ of the respondents agreed that Global Aim Uganda conducted baseline surveys at the start of every project, $43(26.3 \%)$ disagreed while $1(0.6 \%)$ were not sure. The mean was 3.71 and standard deviation was 1.61 that implies that a good number of the respondents agreed with the statement that Global Aim Uganda conducted baseline surveys for its projects as confirmed by a KI.

"We sometimes conduct baseline surveys as a consortium with other partners, we also conduct a general baseline once every year".

However, a quarter of the population disagreed with the statement implying that Global Aim Uganda did not conduct baseline surveys for some of its projects. The main reasons were that Global Aim Uganda had limited funds, sometimes were sub-contracted to implement projects whose baseline surveys were done by other partners, implements continuing projects as reported by some key informants

"We don't conduct baseline surveys for some of the projects because they have already been done other partners". "We don't conduct baseline surveys for projects with small budget"

The study found that $156(95.1 \%)$ of the respondents disagreed that Global Aim Uganda conducts mid-term evaluation, $7(4.3 \%)$ agreed while $1(0.6 \%)$ was not sure. The mean was 1.17 and standard deviation of 0.67 implies that the respondents generally agreed that Global Aim Uganda didn't conduct mid-term evaluation. This was clearly reflected in the statement of one of the key informants.

"I think we only conduct monitoring of project activities but not evaluation. Monitoring is done for reporting to the donor. We shall do evaluation if the donors ask for it and provide the money".

The study indicated that $156(95.1 \%)$ of the respondents disagreed that Global Aim Uganda conducts both end-term evaluation, 4 (2.4\%) agreed while 4 (2.4\%) were not sure. The mean was 1.16 and standard deviation was 0.64 which implies that the majority of the respondents disagreed 
Journal of Business and Strategic Management

ISSN 2520-0402 (Online)

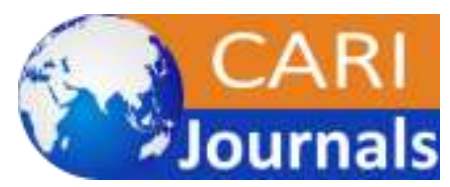

Vol.6, Issue No. 3, pp 57-81, 2021

www.carijournals.org

with the statement that Global Aim Uganda conducts end-term evaluation. This was also echoed by one of the KI who said they never conducted any end-term evaluation.

"After finishing a project, we just go ahead and implement another if funds are available”.

\subsubsection{Utilization of monitoring and evaluation information and performance of Global Aim Uganda}

The responses of the study participants on the statements related to the influence of utilization of M\&E information on the performance of Global Aim Uganda (GAU) were rated on a 5-Likert scale where: 1 - Strongly Disagreed (SD), 2 - Disagreed (D), 3 - Not sure (N), 4 - Agreed (A) and 5 - Strongly Agreed (SA). The extents to which the respondents agreed or disagreed with the statements were presented in the Table 5.

Table 5. Descriptive statistics for the Utilization of M\&E information at Global Aim Uganda

\begin{tabular}{|c|c|c|c|c|c|c|c|}
\hline Statements & SD & $\mathrm{D}$ & NS & A & SA & Mean & Stdev \\
\hline $\begin{array}{l}\text { Reporting influences project } \\
\text { performance }\end{array}$ & & $\begin{array}{r}1 \\
(0.6 \%)\end{array}$ & $\begin{array}{r}2 \\
(1.2 \%)\end{array}$ & $\begin{array}{r}103 \\
(62.8 \%)\end{array}$ & $\begin{array}{r}58 \\
(35.4 \%)\end{array}$ & 4.33 & 0.53 \\
\hline $\begin{array}{l}\text { Dissemination influences } \\
\text { project performance }\end{array}$ & & & $\begin{array}{r}4 \\
(2.4 \%)\end{array}$ & $\begin{array}{r}105 \\
(64.0 \%)\end{array}$ & $\begin{array}{r}55 \\
(33.5 \%)\end{array}$ & 4.31 & 0.51 \\
\hline $\begin{array}{l}\text { Use of M\&E information } \\
\text { influences project } \\
\text { performance }\end{array}$ & & $\begin{array}{r}3 \\
(1.8 \%)\end{array}$ & $\begin{array}{r}5 \\
(3.0 \%)\end{array}$ & $\begin{array}{r}84 \\
(51.2 \%)\end{array}$ & $\begin{array}{r}72 \\
(43.9 \%)\end{array}$ & 4.37 & 0.64 \\
\hline $\begin{array}{l}\text { Follow up influences project } \\
\text { performance }\end{array}$ & & & $\begin{array}{r}1 \\
(0.6 \%)\end{array}$ & $\begin{array}{r}94 \\
(57.3 \%)\end{array}$ & $\begin{array}{r}69 \\
(42.1 \%)\end{array}$ & 4.41 & 0.51 \\
\hline $\begin{array}{l}\text { Feedback mechanism } \\
\text { influences project } \\
\text { performance }\end{array}$ & $\begin{array}{r}1 \\
(0.6 \%)\end{array}$ & & $\begin{array}{r}2 \\
(1.2 \%)\end{array}$ & $\begin{array}{r}98 \\
(59.8 \%)\end{array}$ & $\begin{array}{r}63 \\
(38.4 \%)\end{array}$ & 4.66 & 0.57 \\
\hline $\begin{array}{l}\text { Global Aim Uganda report } \\
\text { on the progress of its project } \\
\text { to stakeholders }\end{array}$ & $\begin{array}{r}2 \\
(1.2 \%)\end{array}$ & $\begin{array}{r}6 \\
(3.7 \%)\end{array}$ & $\begin{array}{r}7 \\
(4.3 \%)\end{array}$ & $\begin{array}{r}70 \\
(42.7 \%)\end{array}$ & $\begin{array}{r}79 \\
(48.2 \%)\end{array}$ & 4.33 & 0.82 \\
\hline $\begin{array}{l}\text { Global Aim Uganda } \\
\text { disseminate project reports } \\
\text { to stakeholders }\end{array}$ & $\begin{array}{r}3 \\
(1.8 \%)\end{array}$ & $\begin{array}{r}2 \\
(1.2 \%)\end{array}$ & $\begin{array}{r}6 \\
(3.7 \%)\end{array}$ & $\begin{array}{r}82 \\
(50 \%)\end{array}$ & $\begin{array}{r}71 \\
(43.3 \%)\end{array}$ & 4.32 & 0.77 \\
\hline
\end{tabular}


Journal of Business and Strategic Management

ISSN 2520-0402 (Online)

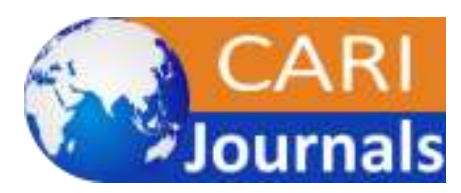

Vol.6, Issue No. 3, pp 57-81, 2021

www.carijournals.org

\begin{tabular}{|l|r|r|r|r|r|r|r|}
\hline $\begin{array}{l}\text { Global Aim Uganda uses } \\
\text { M\&E information in } \\
\text { decision making }\end{array}$ & $\begin{array}{r}3 \\
(1.8 \%)\end{array}$ & $\begin{array}{r}7 \\
(4.3 \%)\end{array}$ & 9 & $\begin{array}{r}54 \\
(5.5 \%)\end{array}$ & $\begin{array}{r}91 \\
(32.9 \%)\end{array}$ & \\
\hline $\begin{array}{l}\text { Global Aim Uganda makes } \\
\text { follow up of projects }\end{array}$ & 5 & 1 & 2 & $6.5 \%)$ & 4.36 & 0.91 \\
\hline $\begin{array}{l}\text { Global Aim Uganda have } \\
\text { mechanisms for feedback }\end{array}$ & $(3.0 \%)$ & $(0.6 \%)$ & $(1.2 \%)$ & $(40.2 \%)$ & $(54.9 \%)$ & 4.43 & 0.82 \\
\hline Mean & & & $\begin{array}{r}6 \\
(1.8 \%)\end{array}$ & $\begin{array}{r}121 \\
(24.4 \%)\end{array}$ & & \\
$(73.8 \%)$ & 4.72 & 0.49 \\
\hline
\end{tabular}

The analysis from Table 5 indicated that 161 (98.2\%) of the respondents agreed that reporting influences project performance, $1(0.6 \%)$ disagreed and $2(1.2 \%)$ were not sure. The mean was 4.33 and standard deviation of 0.53 which implies that majority of the respondents agreed to the statement that reporting influences project performance. This means that reporting if properly done will influence the performance of Global Aim Uganda.

The results showed that $160(97.5 \%)$ of the respondents agreed that dissemination of $\mathrm{M} \& \mathrm{E}$ findings influences project performance while only 4 (2.4\%) were not sure. The mean was 4.31 and standard deviation was 0.51 which implies that the biggest number of the respondents agreed that dissemination of M\&E findings influences project performance at Global Aim Uganda. This shows that dissemination if properly done will influence the performance of Global Aim Uganda.

The study found that $156(95.1 \%)$ of the respondents agreed that utilization of M\&E information influences project performance, $3(1.8 \%)$ disagreed while $5(3.0 \%)$ were not sure. The mean was 4.37 and standard deviation was 0.64 which indicated that the majority of the respondents agreed that the utilization of $M \& E$ information influences project performance. The finding implies that M\&E information if used well will influence the performance of projects at Global Aim Uganda.

The results showed that $163(99.4 \%)$ of the study participants agreed that follow up influences project performance while only $1(0.6 \%)$ was not sure about the statement. The mean was 4.41 and standard deviation was 0.51 that implies that overwhelming majority of the respondents agreed that follow up influences project performance. The study findings therefore imply that follow up if done well contribute to the improved performance of projects.

The results indicated that $161(98.2 \%)$ of the respondents agreed that the availability of feedback mechanisms influences project performance, $1(0.6 \%)$ disagreed and $2(1.2 \%)$ were not sure. The mean was 4.66 and standard deviation of 0.57 implies that majority of the respondents agreed with the statement that availability of feedback mechanisms influences project performance. The finding means that the project performance of Global Aim Uganda will improve if right feedback mechanisms are deployed.

The study found that $149(90.9 \%)$ of the respondents agreed that Global Aim Uganda report on the progress of its project to the stakeholders, 8 (4.9\%) disagreed and 7 (4.3\%) were not sure. The mean was 4.33 and the standard deviation was 0.82 which indicates that majority of the 
Journal of Business and Strategic Management

ISSN 2520-0402 (Online)

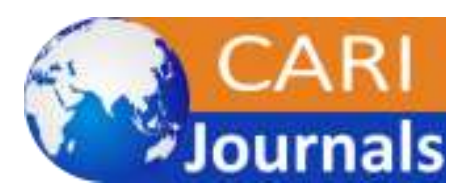

Vol.6, Issue No. 3, pp 57-81, 2021

www.carijournals.org

respondents agreed that Global Aim Uganda report on the progress of its projects to the stakeholders. The few respondents who disagreed or were not sure were mainly new beneficiaries

The study indicated that $153(93.3 \%)$ of the respondents agreed that Global Aim Uganda disseminate M\&E information to stakeholders, 5 (3\%) disagreed and $6(3.7 \%)$ were not sure. The mean of 4.32 and standard deviation of 0.77 shows that majority of the respondents agreed that Global Aim Uganda disseminates M\&E information to stakeholders. This was clearly restated by one of the key informants (KIs).

"We disseminate M\&E information to stakeholders. Our main stakeholders are donors, Office of the Prime Minister (OPM), United Nations High Commission for Refugees (UNHCR), Chief Administrative Officer and the line personnel in the district and subcounties. The challenge we face is that people from local government never acknowledges receipt or replies to reports".

The results showed that $145(88.4 \%)$ of the respondents agreed that Global Aim Uganda utilizes M\&E information, $10(6.1 \%)$ disagreed while $9(5.5 \%)$ were not sure. The mean was 4.36 and the standard deviation was 0.91 which implies that the majority of the respondents agreed that Global Aim Uganda utilizes M\&E information in decision making as echoed by one of KIs.

"We use M\&E information for reporting to the donors, developing new proposals and incorporate findings in improving project implementations".

The study found that $156(95.1 \%)$ of the respondents agreed that Global Aim Uganda makes follow up of projects, $6(3.6 \%)$ disagreed and $2(1.2 \%)$ were not sure. The mean was 4.43 and standard deviation 0.82 implies that that majority of the respondents agreed that Global Aim Uganda makes follow up of projects.

The study revealed that $161(98.2 \%)$ of the respondents agreed that Global Aim Uganda had mechanism for feedback while only $3(1.8 \%)$ were not sure. The mean was 4.72 and standard deviation was 0.49 implying that majority of the respondents had respondents agreed that Global Aim Uganda had mechanisms for feedback. The $3(1.8 \%)$ who were not sure mainly represented the new beneficiaries.

"Our mechanisms for feedback are very clear; we conduct monitoring visits every month, review meetings with partners and meeting of beneficiaries in the field. We also have a Community Based Facilitator in each project area in addition to group chairperson and local councilors. Our beneficiaries can also call any of our staff or walk into our office”.

\subsection{Pearson Correlation Analysis}

Pearson correlation is used to determine the strength and direction of the linear relationship between the predictor variables and the performance of Global Aim Uganda. According to Ratner (2009), correlation coefficient values; between 0 and 0.3 ( 0 and -0.3$)$ indicate a weak positive (negative) linear relationship, between 0.3 and $0.7(-0.3$ and -0.7$)$ indicate a moderate positive (negative) linear relationship, between 0.7 and $1.0(-0.7$ and -1.0$)$ indicate a strong positive (negative) linear relationship. Umwari et al. (2021) applied the scale developed by Ratner (2009) and found a strong positive linear relationship between budgeting and timely completion of projects $(\mathrm{r}=.755)$ and budgeting and level of beneficiary satisfaction $(\mathrm{r}=.754)$. A similar study by Muhayimana and Kamuhanda (2020) found a moderate positive relationship between linking 
M\&E plan to action \& strategic plans and efficiency $(r=.476)$. While, the study also revealed a strong positive relationship between linking M\&E plan to action and strategic plans and project time line $(\mathrm{r}=.987)$. This study used Pearson correlation to determine the strength and direction of the linear relationship between the predictor variables (organizational structure, routine M\&E and utilization of M\&E information) and the performance at Global Aim Uganda. The result of the Pearson Correlation Coefficient ( $r$ ) and level of significance (p) generated from SPSS is presented in Table 6.

Table 6. Pearson Correlation analysis

\begin{tabular}{|c|c|c|c|c|c|}
\hline & & $\begin{array}{c}\text { Organizational } \\
\text { structure }\end{array}$ & $\begin{array}{l}\text { Routine } \\
\text { M\&E }\end{array}$ & $\begin{array}{l}\text { Utilization of } \\
\text { M\&E } \\
\text { Information }\end{array}$ & Performance \\
\hline & Pearson Correlation & 1 & $.307^{* * *}$ & $.418^{* *}$ & .244 \\
\hline \multirow[t]{3}{*}{ Organizational structure } & Sig. (2-tailed) & & .000 & .000 & .002 \\
\hline & $\mathrm{N}$ & 164 & 164 & 164 & 164 \\
\hline & Pearson Correlation & $.307^{* * *}$ & 1 & $.395^{* *}$ & $.403^{* *}$ \\
\hline \multirow[t]{3}{*}{ Routine M\&E } & Sig. (2-tailed) & .000 & & .000 & .000 \\
\hline & $\mathrm{N}$ & 164 & 164 & 164 & 164 \\
\hline & Pearson Correlation & $.418^{* * *}$ & $.395^{* * *}$ & 1 & $.526^{* *}$ \\
\hline \multirow{3}{*}{$\begin{array}{l}\text { Utilization of M\&E } \\
\text { Information }\end{array}$} & Sig. (2-tailed) & .000 & .000 & & .000 \\
\hline & $\mathrm{N}$ & 164 & 164 & 164 & 164 \\
\hline & Pearson Correlation & $.244^{* * *}$ & $.403^{* *}$ & $.526^{* *}$ & $.526^{* *}$ \\
\hline \multirow[t]{2}{*}{ Performance } & Sig. (2-tailed) & .002 & .000 & .000 & $1^{* *}$ \\
\hline & $\mathrm{N}$ & 164 & 164 & 164 & 164 \\
\hline
\end{tabular}

**. Correlation is significant at the 0.01 level (2-tailed).

Results from Table 6 showed a generally positive correlation between the organizational structure, routine $M \& E$ and information with the performance of Global Aim Uganda. The result revealed a significant but weak positive linear relationship between organizational structure and performance of Global Aim Uganda $\left(\mathrm{r}=.244^{* *}, \mathrm{p}=.002,<0.05\right)$ indicating that a change in organizational structure for $M \& E$ results into a corresponding change in performance. The result showed a significant but moderate positive linear relationship between routine M\&E and performance 
$\left(\mathrm{r}=.403^{* *}, \mathrm{p}=.000,<0.01\right)$ implying that improvement in the routine $\mathrm{M} \& \mathrm{E}$ will translate to increased performance by Global Aim Uganda. The analysis showed a significant but moderate positive linear relationship between utilization of M\&E information and performance $\left(\mathrm{r}=.526^{* *}\right.$, $\mathrm{p}=.000,<0.01)$ implying that increase in the utilization of $\mathrm{M} \& \mathrm{E}$ information translates to increase in performance of Global Aim Uganda.

\subsection{Regression analysis}

A multiple linear regression was conducted to determine the influence of routine $\mathrm{M} \& \mathrm{E}$ (independent variable) on the performance (dependent variable) of Global Aim Uganda. The model summary from SPSS is presented in Table 7.

Table 7. Model summary for predictor variables and performance

\begin{tabular}{|l|r|r|r|r|}
\hline Model & \multicolumn{1}{|c|}{$\mathrm{R}$} & \multicolumn{1}{|c|}{ R Square } & Adjusted R Square & $\begin{array}{c}\text { Std. Error of the } \\
\text { Estimate }\end{array}$ \\
\hline 1 & $.568^{\mathrm{a}}$ & .322 & .309 & 2.11423 \\
\hline
\end{tabular}

a. Predictors: (Constant), Utilization of M\&E information, Routine M\&E, Organizational structure. b. Dependent Variable: Performance

Results in Table 7 shows that the coefficient of determination $\left(\mathrm{r}^{2}\right)$ between predictor variables and performance of Global Aim Uganda is 0.322 (32.2\%). The $r^{2}$ value means $32.2 \%$ of the variation in the performance of Global Aim Uganda can be attributed to the predictor variables (organizational structure, routine $\mathrm{M} \& \mathrm{E}$ and utilization of $\mathrm{M} \& \mathrm{E}$ information. Further analysis of variance (ANOVA) between the predictor variables and performance of Global Aim Uganda is presented in Table 8.

Table 8. Analysis of variance (ANOVA)

\begin{tabular}{|c|c|c|c|c|c|c|}
\hline \multicolumn{2}{|c|}{ Model } & Sum of Squares & $\mathrm{df}$ & Mean Square & $\mathrm{F}$ & Sig. \\
\hline \multirow{3}{*}{1} & Regression & 339.924 & 3 & 113.308 & 25.349 & $.000^{\mathrm{b}}$ \\
\hline & Residual & 715.198 & 160 & 4.470 & & \\
\hline & Total & 1055.122 & 163 & & & \\
\hline
\end{tabular}

a. Dependent Variable: Performance

b. Predictors: (Constant), Utilization M\&E information, Routine M\&E, Organizational structure 
Journal of Business and Strategic Management

ISSN 2520-0402 (Online)

Vol.6, Issue No. 3, pp 57-81, 2021

www.carijournals.org

Table 8 shows that the influence of the predictor variables on the performance of Global Aim Uganda was significant at $95 \%$ confidence level $(\mathrm{F}=25.349, \mathrm{p}=0.000,<0.05)$. The regression coefficient for the predictor variables are presented in Table 9.

Table 9. Regression coefficients of the predictor variables against performance

\begin{tabular}{|c|c|c|c|c|c|c|}
\hline \multirow{2}{*}{\multicolumn{2}{|c|}{ Model }} & \multicolumn{2}{|c|}{$\begin{array}{l}\text { Unstandardized } \\
\text { Coefficients }\end{array}$} & \multirow{2}{*}{$\begin{array}{c}\begin{array}{c}\text { Standardized } \\
\text { Coefficients }\end{array} \\
\text { Beta }\end{array}$} & \multirow[t]{2}{*}{$\mathrm{t}$} & \multirow[t]{2}{*}{ Sig. } \\
\hline & & B & Std. Error & & & \\
\hline \multirow{4}{*}{1} & (Constant) & -1.440 & 2.834 & & -.508 & .612 \\
\hline & Organizational structure & -.013 & .081 & -.012 & -.160 & .873 \\
\hline & Routine M\&E & .199 & .062 & .233 & 3.240 & .001 \\
\hline & $\begin{array}{l}\text { Utilization of } \mathrm{M} \& \mathrm{E} \\
\text { information }\end{array}$ & .327 & .056 & .439 & 5.833 & .000 \\
\hline
\end{tabular}

a. Dependent Variable: Performance

From the linear regression equation

$Y=\alpha+\beta X_{1}+\beta X_{2}+\beta X_{3}+\varepsilon$

Where, $\mathrm{Y}$ is the value of performance of Global Aim Uganda (dependent variable) and $\mathrm{X}_{1}$ is the value of organizational structure, $X_{2}$ is the value of routine $M \& E, X_{3}$ is the value of the utilization

of $\mathrm{M} \& \mathrm{E}$ information, $\beta$ is the Beta coefficient of the independent variable (Slope/gradient), $\alpha$ is the intercept (constant) and $\varepsilon$ is the error term. Substituting the values in Table 9 in the linear regression Equation

$Y=-1.440+-.013 X_{1}+.199 X_{2}+.327 X_{3}+\varepsilon$

The constant value of -1.440 is the value of the performance of Global Aim Uganda $(Y)$ when the influence of the predictor variables is zero (all other factors constant). The equation also showed that all factors constant; a unit increase in organizational structure results into -.013 increases in the performance of Global Aim Uganda. The model indicates a negative and non-significant relationship between organizational structure and performance of Global Aim Uganda $(\beta=-.013$, $\mathrm{p}=.873,>0.05)$. The alternate hypothesis that state that organizational structure has a significant influence on the performance of Global Aim Uganda is rejected. 
Journal of Business and Strategic Management

ISSN 2520-0402 (Online)

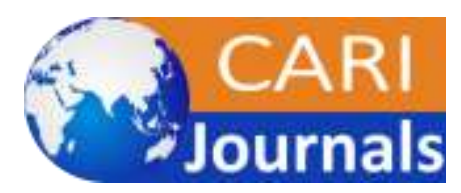

Vol.6, Issue No. 3, pp 57-81, 2021

www.carijournals.org

The result agreed with similar study conducted by Latifi \& Shooshtarian (2014) who found a nonsignificant relationship between mechanistic structure (specified tasks, well defined departments and hierarchy and centralized decision making) and effectiveness caused by lack of flexibility within the organization. Omondi et al. (2017) also found that organizational structure had no significant influence on the performance of banking institutions in Kenya as formalization and specialization within the banks resulted into standalone departments or branches with limited coordination among them. The results disagreed with similar studies conducted by Ajagbe et al. (2016), Andersson et al. (2014) and Rumenya and Kisimbi (2020) who found that organizational structure had a significant influence on performance as it contributed to division of work, coordination of activities, simplified operational processes, clarity of roles and responsibilities, reporting lines and clear definition of the functions of the M\&E unit.

The regression equation also showed that all factors constant; a unit increase in routine M\&E results into .199 increases in the performance of Global Aim Uganda. The model indicates a positive and significant relationship between routine $\mathrm{M} \& \mathrm{E}$ and performance of Global Aim Uganda $(\beta=.199, \mathrm{p}=.001,<0.05)$. The alternate hypothesis that state that routine $\mathrm{M} \& \mathrm{E}$ has a significant influence on the performance of Global Aim Uganda is accepted. The study found a statistically significant relationship between routine $\mathrm{M} \& \mathrm{E}$ and performance at Global Aim Uganda. This finding concurred with a number of previous studies (Mbithi \& Kiruja, 2015; Muhayimana \& Kamuhanda, 2020; Umwari et al., 2021). Routine M\&E contributes to project performance because it provides an opportunity for learning and improvement, resource mobilization, accountability, stakeholder engagement, beneficiary empowerment and partnerships (Wongtschowski et al., 2016).

The equation also showed that all factors constant; a unit increase in utilization of M\&E information results into .327 increases in the performance of Global Aim Uganda. The model indicates a positive and significant relationship between utilization of M\&E information and performance of Global Aim Uganda $(\beta=.327, p=.000,<0.05)$. The alternate hypothesis that state that utilization of $M \& E$ information has a significant influence on the performance of Global Aim Uganda is accepted. This concurred with the views of (Gamba et al., 2020) who indicated that utilization of $\mathrm{M} \& \mathrm{E}$ information resulted in to increased performance of organizations implementing malaria control program in Uganda. Gorgen and Kusek (2009) argued that utilization of $M \& E$ information improves performance by enabling decision makers take timely corrective measures thus ensuring the project is on track to achieving its set objectives.

\subsection{SUMMARY, CONCLUSIONS AND RECOMMENDATIONS}

\subsection{Summary of the study findings}

\subsubsection{Organization structure and the performance of Global Aim Uganda}

The findings of the study revealed that 153 (93.3\%) of the respondents agreed that Global Aim Uganda had an organogram with M\&E unit a fact confirmed by a mean value of 4.07. Majority 159 (96.9\%) of the respondents agreed that there is a clear reporting line within the organization with a mean of 4.39. All $164(100 \%)$ the respondents agreed that staff at Global Aim Uganda including those in the M\&E unit had a clearly defined responsibilities with a mean value of 4.59. The results also indicated that $157(95.7 \%)$ the M\&E unit had a clearly defined functions with a 
Journal of Business and Strategic Management

ISSN 2520-0402 (Online)

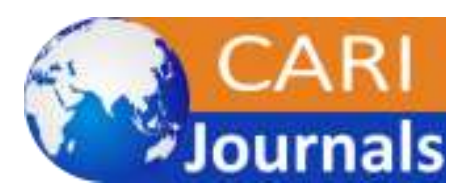

Vol.6, Issue No. 3, pp 57-81, 2021

www.carijournals.org

mean score of 4.32. Results from the Pearson Correlation revealed a weak positive linear correlation that is statistically significant between organizational structure and performance of Global Aim Uganda $\left(\mathrm{r}=.244^{* *}, \mathrm{p}=.002,<0.05\right)$. Result from the regression analysis revealed that organizational structure had a negative and non-significant influence on the performance of Global Aim Uganda $(\beta=-.013, p=.873,>0.05)$. This means that we reject the alternate hypothesis which stated that organizational structure has a significant influence on the performance of Global Aim Uganda.

\subsubsection{Routine M\&E and the performance of Global Aim Uganda}

Results from the study revealed that $153(93.3 \%)$ of the study participants agreed that Global Aim Uganda conducts routine with a mean score of 4.47. The study found that majority $120(73.2 \%)$ of the respondents agreed that Global Aim Uganda conducted baseline surveys at the start of every project while a quarter $43(26.3 \%)$ of the respondents disagreed with a mean of 3.71 . The study found that $156(95.1 \%)$ of the respondents disagreed that Global Aim Uganda conducts mid-term evaluation with a mean of 1.17. The study also indicated that $156(95.1 \%)$ of the respondents disagreed that Global Aim Uganda conducts end-term evaluation with a mean of 1.16. Results from the Pearson Product Moment Correlation revealed a moderate positive linear correlation that is statistically significant between routine $\mathrm{M} \& \mathrm{E}$ and performance of Global Aim Uganda $\left(\mathrm{r}=.403^{* *}, \mathrm{p}=.000,<0.01\right)$. The result signifies that improvement in the routine M\&E subvariables; baseline surveys, routine monitoring, mid-term evaluation and end-term evaluation will translate to increased performance by Global Aim Uganda. The coefficient of determination value between routine $M \& E$ and performance was 0.146 revealing that $14.6 \%$ of the variation in the performance of Global Aim Uganda can be explained by the routine M\&E. Result from the regression analysis revealed that routine $M \& E$ has a positive and significant influence on the performance of Global Aim Uganda $(\beta=.199, \mathrm{p}=.001,<0.05)$. Therefore, the alternate hypothesis which stated that routine $\mathrm{M} \& \mathrm{E}$ has a significant influence on the performance of Global Aim Uganda was accepted.

\subsubsection{Utilization of M\&E information and the performance of Global Aim Uganda}

Results from the study found that majority 149 (90.9\%) of the respondents agreed that Global Aim Uganda report on the progress of its project to the stakeholders with a mean of 4.33. The study indicated that $153(93.3 \%)$ of the respondents agreed that Global Aim Uganda disseminate M\&E information to stakeholders with a mean of 4.32. The results revealed that $145(88.4 \%)$ of the respondents agreed that Global Aim Uganda utilizes M\&E information with a mean score of 4.36. The study found that $156(95.1 \%)$ of the respondents agreed that Global Aim Uganda makes follow up of projects with a mean of 4.43. The study revealed that $161(98.2 \%)$ of the respondents agreed that Global Aim Uganda had mechanism for feedback with a mean of 4.72 and standard deviation was 0.49. Results from the Pearson Product Moment Correlation revealed indicated a moderate positive linear correlation that is statistically significant between utilization of M\&E information and performance of Global Aim Uganda $\left(\mathrm{r}=.526^{* *}, \mathrm{p}=.000,<0.01\right)$. The coefficient of determination value between utilization of $M \& E$ information and performance was 0.218 revealing that $21.8 \%$ of the variation in the performance of Global Aim Uganda can be explained by the utilization of $M \& E$ information. Result from the regression analysis revealed that utilization of $M \& E$ information has a positive and significant influence on the performance of Global Aim Uganda $(\beta=.327, p=.000,<0.05)$. This means that we accept the alternate hypothesis which stated 
Journal of Business and Strategic Management

ISSN 2520-0402 (Online)

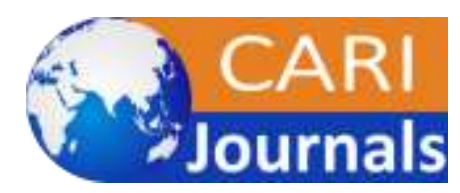

Vol.6, Issue No. 3, pp 57-81, 2021

www.carijournals.org

that utilization of $M \& E$ information has a significant influence on the performance of Global Aim Uganda.

\subsection{Conclusion}

\subsubsection{Organizational structure and performance of Global Aim Uganda}

The general finding indicated that Global Aim Uganda had an organizational structure with an $\mathrm{M} \& \mathrm{E}$ unit with clear reporting line and responsibilities. However, the functions of the M\&E unit were not clearly defined. This came out clearly as the M\&E unit never trained staff in the organization on M\&E activities. The M\&E unit had only one staff (the M\&E officer) who didn't receive any $M \& E$ training apart from the recent one conducted by an implementing partner (GIZ) at the time of the study. But the M\&E officer worked hand in hand with other project staff to perform $M \& E$ duties. Therefore, refining the functions of the $M \& E$ unit, staff responsibilities and training of staff to improve their capacity is key to improving the performance of Global of Global Aim Uganda.

\subsubsection{Routine M\&E and performance of Global Aim Uganda}

General finding indicated that Global Aim Uganda conducted some form of routine M\&E. The organizational mainly conducted routine monitoring but not evaluation. The routine monitoring was basically done to meet donor demand. The organization did not conduct baseline surveys for some of its projects. The main reason why baseline surveys for some of the projects were not conducted was attributed to financial constraints. The few baseline surveys which the organization participated in were in partnership with donors or other implementing partners. It was also reported that the organization conducts a major baseline surveys once every year. However, this baseline surveys were not project specific which call in to question its practical application for result based M\&E. Therefore, the organization should consider putting emphasis on project specific baseline surveys, improved routine monitoring, evaluating its projects, training of staff and allocating adequate financial and human resources as critical steps in improving its performance.

\subsubsection{Utilization of M\&E information and performance of Global Aim Uganda}

The organization reported utilization of $M \& E$ information in areas such as informed decision making, baseline for new projects and development of new proposals. However, no documentary evidence was availed to substantiate the claim. Internal reporting of $\mathrm{M} \& \mathrm{E}$ information is being done with a lot of delays. The quality of the reporting was also cited as an issue such a senior person usually takes a lot of time trying to review before sharing with external stakeholders. Adequate stakeholder feedback mechanisms (phone, email, review meetings, field visits and community-based representative) existed. However, feedback on reports especially from stakeholders from the side of the District Local Government was reported to be a challenge. Therefore, improving the use of M\&E findings, timely and quality reporting internal reporting, improvement on mechanisms for feedback are needed for improved performance of Global Aim Uganda.

\subsection{Recommendation}

\subsubsection{Organizational structure and performance of Global Aim Uganda}

- Broaden the functions of the M\&E unit to include training of staff. 
Journal of Business and Strategic Management

ISSN 2520-0402 (Online)

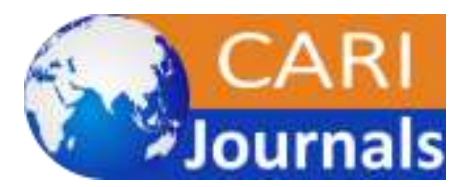

Vol.6, Issue No. 3, pp 57-81, 2021

www.carijournals.org

- Management should consider hiring additional personal in the M\&E unit

- Staff roles and responsibilities should be revised to capture elements of M\&E such that they don't look at it as an additional task.

- There is need to build the capacity of the M\&E officer given he didn't have any formal training in $\mathrm{M} \& \mathrm{E}$ or any capacity building support except once.

\subsubsection{Routine M\&E and performance of Global Aim Uganda}

- The organization should conduct project specific baseline surveys.

- The organization should lobby for adequate funds for baseline surveys, monitoring and evaluation from donors.

- There is need for the organization to start conducting mid-term and end-term evaluations for its projects.

- The organization should empower beneficiaries to do data collection and reporting using simple tools.

\subsubsection{Utilization of M\&E information and performance of Global Aim Uganda}

- Train staff and provide tools for internal reporting.

- The organization should come up with a service level agreement for reporting to stamp out delays in reporting. In addition, an inquiry has to be instituted to explore the reasons for delay in reporting.

- The organization need to explore the reasons as to why they don't receive feedbacks from some of their reports from other stakeholders District.

\subsection{Areas for further research}

Future study should focus on establishing the influence of M\&E capacities on the performance of National Non-Governmental Organizations (NNGOs) using both qualitative and quantitative approaches.

\section{REFERENCES}

Ajagbe, M. A., Micheal, N., Udo, E. E., \& Peter, O. F. (2016). How organizational structure aids business performance. International Journal of Research in Commerce \& Management, 7(8), 64-68. https://doi.org/10.1177/0002764294037007005

Andersson, J., Zbirenko, A., \& Medina, A. (2014). Effect of organizational structure, leadership and communication on efficiency and productivity: A qualitative study of a public health care organization. https://www.diva-portal.org/smash/get/diva2:735889/fulltext01.pdf

Arnold, R. D., \& Wade, J. P. (2015). A definition of systems thinking: A systems approach. Procedia Computer Science, 44, 669-678. https://doi.org/10.1016/j.procs.2015.03.050

Barr, A., Fafchamps, M., \& Owens, T. (2003). Non-Governemntal Organizations in Uganda: A report to the Government of Uganda. Centre for the study of African Economies, Oxford University. https://sarpn.org/documents/d0000716/NGO_Uganda_Dec2003.pdf

Biwott, T., Egesah, O., \& Ngeywo, J. (2017). Importance of monitoring and evaluation in the sustainability of Constituency Development Fund (CDF) Projects in Kenya. International 
Journal of Business and Strategic Management

ISSN 2520-0402 (Online)

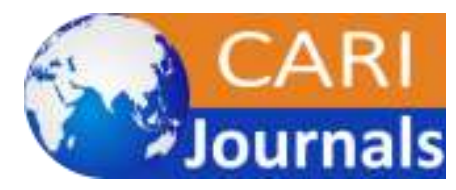

Vol.6, Issue No. 3, pp 57-81, 2021

www.carijournals.org

Journal of Management \& Social Sciences, 7(1), 45-51. https://doi.org/10.21013/jmss.v7.n1.p6

Bougheas, S., Isopi, A., \& Owens, T. (2012). How do donors allocate funds to NGOs? Evidence from Uganda. CREDIT Research Paper, No. 12/08. The University of Nottingham, Centre for Research in Economic Development and International Trade (CREDIT), Nottingham.

Cordon, C. P. (2013). System Theories: An Overview of Various System Theories and Its Application in Healthcare. American Journal of Systems Science, 2(1), 13-22. https://doi.org/10.5923/j.ajss.20130201.03

Fincham, J. E. (2008). Response rates and responsiveness for surveys, standards, and the Journal. American Journal of Pharmaceutical Education, 72(2), 43. https://doi.org/10.5688/aj720243

Gamba, P., Tukei, J. M. O., \& Birungi, S. (2020). Effect of Implementation Factors on Monitoring \& Evaluation Results Utilization: Evidence from the Malaria Control Programs in Mukono District, Central Uganda Specioza Birungi. International Journal of Technology and Management Community, 6(1), 1-11.

Ghalem, Â., Okar, C., Chroqui, R., \& Semma, E. (2016). Performance : A concept to define. https://doi.org/10.13140/RG.2.2.24800.28165

Goldstein, H. (1975). Some critical observations on the relevance of social systems theory for social work practice. Canadian Journal of Social Work Education, 1(3), 13-23. http://www.jstor.org/stable/41668830 .

Gorgens, M., \& Kusek, J. Z. (2009). Making monitoring and evaluation systems work: A capacity development toolkit. Washington, DC. World Bank. https://doi.org/10.1596/9780-8213-8186-1

Holvoet, N., \& Inberg, L. (2015). Diagnostic Review of the Monitoring and Evaluation System of Uganda's Education Sector: Selected Findings and Discussion. Journal of Education and Training, 2(1), 134-154. https://doi.org/10.5296/jet.v2i1.6720

Jones, B. (2013). The making of meaning: Churches, development projects and violence in Eastern Uganda. Journal of Religion in Africa, 43, 75. https://doi.org/10.1163/1570066612341245

Kasule, J. S. (2016). Factors affecting application of results based monitoring and evaluation system by nurture Africa (MSc Thesis). School of Business \& Management, UTAMU, Kampala, Uganda.

Latifi, M., \& Shooshtarian, Z. (2014). The effects of organizational structure on organizational trust and effectiveness. Polish Journal of Management Studies, 10(2), 73-84. https://doi.org/10.2139/ssrn.1107319

Lenfant, F., \& Rutten, R. (2013). Cordaid's experience with impact evaluation. Development in Practice, 23(1), 46-56. https://doi.org/10.1080/09614524.2013.753412

Lutabingwa, J., Gray, K. R., \& Skinner, E. P. (1997). NGOs in sub-saharan Africa: Developing 
Journal of Business and Strategic Management

ISSN 2520-0402 (Online)

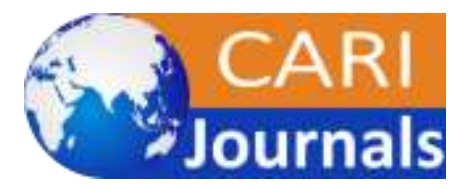

Vol.6, Issue No. 3, pp 57-81, 2021

www.carijournals.org

critical capacity for policy advocacy. International Journal on World Peace, 14(3), 3570.

Martens, K. (2002). Mission impossible? Defining nongovernmental organizations. International Journal of Voluntary and Nonprofit Organisations, 13(3), 271-285. https://doi.org/10.1023/A:1020341526691

Masuku, N. W. K., \& Ijeoma, E. O. C. (2015). A Global Overview of Monitoring and Evaluation (M\&E) and its Meaning in the Local Government Context of South Africa. Africa's Public Service Delivery and Performance Review, 3(2), 1-10. https://doi.org/10.4102/apsdpr.v3i2.79

Mbithi, V., \& Kiruja, I. \&dr E. (2015). Role of Monitoring and Evaluation on Performance of Public Organization Projects in Kenya: a Case of Kenya Meat Commission. International Journal of Innovative Development \& Policy Studies, 3(3), 12-27. http://seahipaj.org/journals-ci/sept-2015/IJIDPS/full/IJIDPS-S-2-2015.pdf

Meles, C., Pels, J., \& Polese, F. (2010). A brief review of systems theories and their management applications. A Brief Review of Systems Theories and Their Managerial Aapplications, 2(1-2), 126-135. https://doi.org/10.1287/serv.2.1

Mueller-Hirth, N. (2012a). If you don't count, you don't count: Monitoring and evaluation in South African NGOs. Development and Change, 43(3), 649-670. https://doi.org/10.1111/j.1467-7660.2012.01776.x

Mueller-Hirth, N. (2012b). If you don't count, You don't count: Monitoring and evaluation in South African NGOs. Development and Change, 43(3), 649-670. https://doi.org/10.1111/j.1467-7660.2012.01776.x

Muhayimana, O., \& Kamuhanda, J. K. (2020). The relationship between Monitoring and Evaluation (M\&E) practices and public projects performance in Rwanda with reference to Science and Technology Skills. International Journal of Advanced Scientific Research and Management, 5(9), 98. https://doi.org/10.36282/ijasrm/5.9.2020.1758

Nasambu, J. (2016). Factors influencing the performance of monitoring and evaluation systems in Non Governmental Organizations in Lira District, Northern Uganda (MSc Thesis). School of Business \& Management, UTAMU. Kampala, Uganda.

Nikolaev, M. Y., \& Fortin, C. (2020). Systems thinking ontology of emergent properties for complex engineering systems. Journal of Physics: Conference Series, 1687(1), 1-9. https://doi.org/10.1088/1742-6596/1687/1/012005

Okeny, G. (2015). Monitoring \& Evaluation system \& performance of projects among NGOS in Uganda: A case study of War Child Holland-Livelihood project (MSc Thesis). School of Management, Uganda Management Institute. Kampala, Uganda. http://umispace.umi.ac.ug/handle/20.500.12305/120

Omona, J., \& Mukuye, R. (2013). Problems of credibility of NGOs in Uganda: Implications for theory and practice. Voluntas, 24, 311-334. https://doi.org/10.1007/s11266-011-9254-9

Omondi, J. S., Rotich, G., Katuse, P., \& Senaji, T. (2017). The Relationship between 
Journal of Business and Strategic Management

ISSN 2520-0402 (Online)

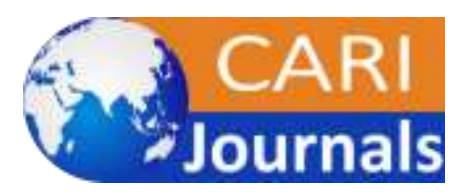

Vol.6, Issue No. 3, pp 57-81, 2021

www.carijournals.org

Organization Structure and Performance in Commercial Banks in Kenya: The Mediating Role of Innovation. International Journal of Academic Research in Business and Social Sciences, 7(4), 633-657. https://doi.org/10.6007/ijarbss/v7-i4/2838

Owa, O. E., Owa, W. E., \& Owa, W. E. (2017). The role of non-governmental organizations (NGOs) in strengthening civil society and democratic development. Journal of Arts and Management, 2(2), 91-98.

Porter, S., \& Goldman, I. (2013). A Growing Demand for Monitoring and Evaluation in Africa. African Evaluation Journal, 1-9. https://doi.org/10.4102/aej.v1i1.25

Ratner, B. (2009). The correlation coefficient: Its values range between $+1 /-1$, or do they. Journal of Targeting, Measurement and Analysis for Marketing, 17(2), 139-142. https://doi.org/10.1057/jt.2009.5

Rumenya, H., \& Kisimbi, D. J. M. (2020). Influence of Monitoring and Evaluation Systems on Performance of Projects in Non-Governmental Organizations: A Case of Education Projects in Mombasa County, Kenya. Journal of Entrepreneurship and Project Management, 5(2), 46-66. https://doi.org/10.47941/jepm.494

Samsonowa, T. (2012). Industrial research performance management: Key performance indicators in the ICT industry. Walldorf, Germany. Physica-Verlag.

Sayin, H. Ü. (2016). A short introduction to system theory: Indispensable postulate systems and basic structures of the systems in quantum physics, biology and neuroscience. NeuroQuantology, 14(1), 126-142. https://doi.org/10.14704/nq.2016.14.1.855

Sulemana, M., Musah, A. B., \& Simon, K. K. (2018). An assessment of stakeholder participation in monitoring and evaluation of district assembly projects and programmes in the Savelugu-Nanton Municipality Assembly, Ghana. Ghana Journal of Development Studies, 15(1), 173-195. https://doi.org/10.4314/gjds.v15i1.9

UBOS. (2016). National service delivery survey 2015 report. Kampala, Uganda. https://www.ubos.org/wp-content/uploads/publications/03_20182015_NSDS_report.pdf

Umwari, D., Kamuhanda, K. J., \& Nyamweya, N. M. (2021). Monitoring and Evaluation Practices and Project Performance in Rwanda: A Case of the Horticulture Project at BRAMIN Ltd. International Journal of Advanced Scientific Research and Management, 6(6), 64-73. https://doi.org/10.36282/ijasrm/6.6.2021.1826

Von-Bertalanffy, L. (1968). General system theory: Foundation, development \& application. New York, NY. George Braziller. https://doi.org/10.4324/9781351310000-6

Wongtschowski, M., Oonk, L., \& Mur, R. (2016). Monitoring and Evaluation for Learning (KIT working papers 2016-3). https://www.kit.nl/wp-content/uploads/2018/08/Monitoringand-evaluation-for-accountability-and-learning.pdf

Yamane, T. (1967). Statistics: An Introductory Analysis, 2nd Edition, New York: Harper and Row. 